Author: Georgina Murray

Institution: Griffith University

Email address: g.murray@griffith.edu.au

Author biography: Georgina Murray is an associate Professor at Griffith University, she teaches political economy and has published three books the latest being Financial elites and transnational Business: who rules the world? (2012).

Acknowledgments: For colleagues and friends writing and contributing new ideas to this topic all the time- Bill Robinson, Jerry Harris, Bill Carroll, Jeb Sprague, and Jason Strauna and to previous, and current, co writers Dr. Jenny Chester and Professor David Peetz for their ideas and inspiration.

Abstract: Who rules the world? This paper suggests that the top 0.1 per cent do. They are a heterogeneous class fraction that own and/or control the circuit of capital at different times, in different global locations, for different rewards, with different workforces and regulations. Their power base is this ownership and control of capital and not power from their individual charisma, authority or influence (though these may follow). This class power is hegemonic and at capitalism's core. The methods used are triangulated between statistical data on the top 0.1 and .01 per cent, secondary sources - newspapers and books - and original collated data from the Bureau Van Dyk database. From this the article looks at (1) Who the emerging global ruling class are? (2) What their means are in the class struggle? and (3) What are the likely consequences for this unequal power distribution for the future of global society?

Title: We rule the world: an emerging global class fraction?

Purpose: To investigate who rules the world? The hypothesis is that it is the $.1 \%$ of owners and controllers of capital.

Methodology/approach: Dyk and The World Top Incomes database - to look at distributions of income and wealth (stock ownership). This is supplemented with secondary source analysis and with some interviews.

Findings: The top point one per centers, the wealthy, those on the top incomes and transnational capitalist class are all distinct but overlapping categories that describe the (white) men and (few) women who hold power through their ownership and/or control of capital, and who are thereby directly or indirectly able to act hegemonic-ally, on an emerging global basis.

Research limitations/implications: Theorists of the global school of capitalism Alveredo, F, Atkinson, A. Piketty, T \& Saez, E. (2013) The top 1 percent in International and historical Perspective, Journa; of Economic Perspectives, v.27, n.3, Summer, pp.3-20.argue that there has been a qualitatively new twenty-first century transnational capitalism in the process of emerging (see Robinson 2012a). This paper tests this assumption and relates it to the work of Hamm 2010.

Social implications: The flip side of this progressively widening concentration of income and wealth into fewer $(0.1 \%)$ hands brings new lows to the polarization of class, exploitation and domination. All of these have intensified since the 1980s with the end of the Keynesian Compromise. This north/ south accentuated division has implications for social justice.

Originality/value of paper: This seeks to identify empirical evidence to support the theory of an emerging transnational capitalist class.

Keywords: wealth, income, concentration, centralization, one percent-ers; finance capital; class struggle; sustainability; financialisation.

Category of paper: Article for edited journal collection 


\section{We rule the world: an emerging class fraction?}

When I was young, I thought that money was the most important thing in life; now that I am old, I know it is". [Oscar Wilde]

\section{Introduction}

The we in 'we rule the world' are the 0.1 per cent of the wealth holding 'corporate bigwigs and wheeler dealers' (Krugman 2011); they are the top 1\%, income earners and they are the top transnational capitalist class [or TCC]. The TCC are the winners of the capitalist jackpot and maybe the only winners of the 2008-2013 global financial crisis (GFC) (see Chester 2014, Hamm 2010a, Hamm 2010b:1008, Leopold 2009a). They increased their market share (Murray and Peetz 2012) by an estimated \$30 billion in 2009 ( Leopold 2009b) and now five years later they are worth collectively more (Kroll 2013, Lopez 2013) with the 400 wealthiest Americans are worth just over \$2 trillion, roughly equivalent to the GDP of Russia (Kroll 2013) which is $\$ 300$ billion more than the year before. These TCC are men (mostly) and women who as individuals have power through their ownership and/or control of capital which enables them to act as a hegemonic fraction of capital that is positioning itself to become a global ruling class (Robinson 2014:1).

The TCC are not an elite - they are a class - as defined by their relationship to the means of production. The enormous growth in wealth was unleashed, post 1980, by the neoliberal counter revolution (i.e. using the theories of Friedman and Freidman 1980, Von Hayek 1944:1008) enabling right and left right wing politicians to use the language of capital-liberating-policy and put it into everyday commonsensical meaning (Beder 2006, Cockett 1995, Murray and Pacheco 2000, Murray 2004). In this post Keynesian period we are experiencing financialization that is, it began in the 1980s with the deregulatory reforms (usually but not always enforced by neoliberal governments); when financial institutions and their transactions become more dominant and in size and influence (See Dicken 2003:201, Kus 2012); and whereby capital accumulation occurs mostly through 
financial means rather than through trade or commodity production (see Connell and Dados 2014). We are now in a period where a finance class fraction are poised to take an even greater role in the processes of capital accumulation.

This article will enlarge upon 1 . The argument, as to whether this top layer is a class based on their extraordinary relationship to the means of production; 2. Identify the evidence to find the emerging global ruling class; 3. Look at the TCCs the structures and processes as they relate to the circuit of capital and last 5.look at some individual examples of this capital distribution?

\section{Defending the argument}

In this argument the TCC, are of both the top wealth holders and the top earned income, that is, they are a class not an elite. Their unifying characteristic, as the top-of-the-top one per cent, is that their wealth and/or high income is defined in relation to their ownership and control of the means of production. They are a class fraction who operate within the structural field of the circuits of capital (Krippner 2005).

This challenges elite theories who argue that the TCC are globalizing bureaucrats or politicians (Marx 1974, Palloix 1977), globalizing professionals, academics (Sklair 2005) 515); military men (sic) (Dicken 2007); or consumerist elites (Mills 1958:1). The TCC may also have these statuses, that is, they may overlap with their class position but they are not definitional. Elite persons, as described, maybe be powerful, accepting that power means the ability to make someone do what they do not want to do (Sklair 2002) but these elite roles are the roles of the TCC's footmen or 'members of the second circle'. (Hamm 2010a:1008). That is, these elite roles enable the less powerful to do the work of the TCC. Two examples of this could be, the first, found under this newspaper heading 'Former British Prime Minister Tony Blair offered to act as a secret adviser to Rupert Murdoch during his media empire's phone-hacking scandal' (Holden 2014) . Or again in regard to David Cameron's relations with the Murdoch Press “David Willett's, the universities minister, admitted the relationship between politicians and some newspapers became too close”. (Watts 2012) 
Second, there are the definitional problems associated with being the top-of-thetop one per cent that begin with the distinction between the basis of their wealth, financial wealth and income (though the distinction between the two types of income can be 'blurry in some cases'(Alvaredo et al. 2013)or the difference is largely hypothetical 'as in reality those at the very top of the wealth distribution usually have the most income.' (Alvaredo et al. 2013) Alvaredo et al provide empirical information to show that 'the degree of association [between top earned and capital income] appears strong' (Alvaredo 2013:15). For only a few (nineteen per cent in 2008) with an income of over $\$ 10$ million earned their income through a job; most received it through interest, dividends, or royalties. (Domhoff 2014b:1) And there has been an enormous growth in the amounts paid to executive in salaries, relative to real average earnings in the period from 1980-2003. In this time executive pay has grown 560 per cent reflecting, the shifting sources of wealth in capital from dividends, interest and royalties to "salaries" (senior executive pay). (Norris 2010:B-5)

Third, is a locational problem. I argue that the top-of-the-top one percent are a transnationalising class fraction, because even when they are located nationally (e.g. primarily operating within one nation state), or internationally (e.g. using limited national market integration) or indeed transnationally (e.g. using global productive product chains) part of their investments, if not all of them, are likely to be liquid and located globally. This is a transnational class fraction because the top-of-the-top capitalist class has the wealth to produce and purchase assets anywhere in the world and they do so. The TCC operate in this increasingly transnationalising world where capital penetrates all global regions and all nation states, operating with and through loose transnational networks of state apparatus, that function to facilitate capital accumulation, maintain and sustain the top-of-thetop one per cent’s class power. (Peetz and Murray 2013)

In this argument the top-of-the-top one per cent have the wealth to be a truly transnationalising capitalist class (TCC) because they are the primary owners of wealth and income and/or are the controllers of the means of capitalist production. This shared privileged relationship to the means of production does not, however, 
make them a homogenous group. They are diverse. They act differently in different geographic locations and at different times in history, they employ different means - money, productive or commodity - capital, that plays a different roles in the circuit of accumulation (Carroll 2010:10, 37, Robinson 2014:4). As a class fraction the TCC operate processes of capital accumulation that are as old as capitalism itself but their current environment, and the diversity of these current markets mean they act within a changing financial architecture. (Harvey 2010) Actors within this financialization architecture are reacting against the Keynesian compromise (1945-1980) when the state socialized the costs of production replacing it it with their free market sporting a free market set of mechanisms for wealthy enrichment.

\section{Overview of the transnational financial world}

Financialization from the 1980s unleashed speculative financial profits that Susan Strange has variously called ‘casino capitalism' (Krippner 2005) and 'mad money' (Strange 1996): 24). The emergence of this mad money has been paralleled by the plethora of cheapened transnational production and services (Strange 1986) meaning cheap consumer goods, transportation systems and new technologies (particularly the internet) which further reduce costs and facilitates rapid cross border capital flows in real time (Dicken 2003, McMichael 1996). Deregulation in the finance sector allowed the development of new instruments to further facilitate accumulation, such as, floating rate notes; currency swaps; loan sales; Euro commercial paper; interest rate swaps etc. on which more and more speculative profits can be made (Harris 2012). The system of credit has again become a 'focal point in the allegedly national banks and the big money-lenders and usurers that surround them, is one enormous centralization and gives this class of parasites a fabulous power not only to decimate the industrial capitalists periodically but also to interfere in actual production in the most dangerous manner- and this crew know nothing of production and have nothing at all to do with it. (Henwood 2005) As a result of this, national economies have differentially reorganized and reintegrated, as parts of a global whole that is now qualitatively different from earlier epochs. (Marx 1894a, Marx 1894b, Marx 1981:chapter 33) 
The changed financial architecture has enables a filtering through of the neoliberalism counter-revolution organized through conservative think tanks. (Robinson and Harris 2000, Robinson 2012b) Their neoliberal ideology became the policy to deregulate finance, to apply supply side economics (including regressive taxation) but at its heart was an anti unionism, anti welfarism and an anti nation state protectionism opening the way for businesses to enrich themselve. Neoliberal policies became the preferred politics of core politicians (of all persuasions) from the 1980s and the deregulation it unleashed became lava flows of liquid capital across borders or indeed wherever the TCC were able to go to maximize profits.

Even though profit was geographically unevenly distributed (Cockett 1995, Hamm 2010a:1011) capital was again free to move forward into a newly (largely) unregulated world. This process was helped by the free use of tax havens (Dicken 2007, Robinson 2012a) and the related establishment of trusts. (see Van Fossen 2012:76-99)

At no stage does this transnational capital theory deny the importance of the complex role of the nation state in the circuit of money. The state plays a crucial role in process of financialization. Much of the risk taking behavior in the Great Financial Crisis [GFC] has been credited to the Too-Big-to-Fail-Banks [TBTF banks] policy exercised by nation states. In a study of 200 banks in over 45 countries a team of US economists found that a 'increase in government support leads to a higher ratio of impaired loans ... [and] arise in bank risk taking” (Madoff 2010). As a result an IMF study found that US banks were carrying state subsidies worth \$US70 billion in 2012; the European banks \$US300 billion and in the UK and Japan up to \$US110 billion. In many countries, the value of assets in the banking sector relative to GDP has grown dramatically since 2000, while the number of banks has dropped (Letts 2014) or concentration and centralization has occurred through crisis and small capital collapse.

The state further facilitates the infrastructural needs of capital through the control, education and organization of labour. (IMF 2014) Indeed the state’s role has widened in the irregular facilitation, discipline and organization of large pools of legal and illegal labor because labour too is internationalizing (Strauna 2009). 
With walls erected and dismantled (Brown 2011) to control labour flows and in other areas where barriers to transnational global growth are disappearing (Grossman and Woll 2013). As regulations inhibiting capital were systematically lifted everywhere the ruling class fraction has become increasingly wealthy, as follows.

\section{Wealth - Capital Income}

Wealth, or capital income is 'rents dividends, interest and realized capital gains' (Alveredo et al. 2013:10) is very polarizing socially as is evident in the US where in 2010 the bottom 99 per cent held 65 per cent of the wealth and the top 1 per cent held 35 per cent of it (Robinson 2012b:353). We can see clearly this pattern of wealth distribution and the cut off point for the top one percent in the following table (Table 1). The table also highlights the chasm between wealth held as mean household financial wealth for the top one per cent (over \$15 million dollars) contrasted to the absence of wealth amongst the poor, rather they have debt. Where the bottom 40 per cent are more than $\$ 14,000$ in debt.

Table 1: Wealth Distribution in the US in 2012 (by \$US 2010)

\begin{tabular}{|l|r|r|}
\hline $\begin{array}{l}\text { Wealth or income } \\
\text { class }\end{array}$ & $\begin{array}{l}\text { Mean } \\
\text { household net } \\
\text { worth (US\$) }\end{array}$ & $\begin{array}{l}\text { Mean household financial } \\
\text { wealth (non home) (US\$) }\end{array}$ \\
\hline & $16,439,400$ & $15,171,600$ \\
\hline top 1 per cent & $2,061,600$ & $1,719,800$ \\
\hline top 20 per cent & 216,900 & 100,700 \\
\hline 60-80th percentile & 61,000 & 12,200 \\
\hline 40th-60th percentile & $-10,600$ & $-14,800$ \\
\hline Bottom 40 per cent & & \\
\hline Source: (Wolff 2012 in & & 140 \\
\hline
\end{tabular}

The content of investment is becoming more aware of impending crisis. "The changing mix of global portfolio investors is likely to make overall portfolio flows more sensitive to global financial shocks. (Wolff (2012). When we look over time (1998-2010) in figure 1 we can see that the wealth of the very top 400 global billionaires has been getting steadily higher with only a sudden dip in 2009, following the global financial crisis, but steeply moving toward recovery by 2010. (IMF 2014) 
Figure 1: The total wealth of the top 400 global billionaires 1998-2010

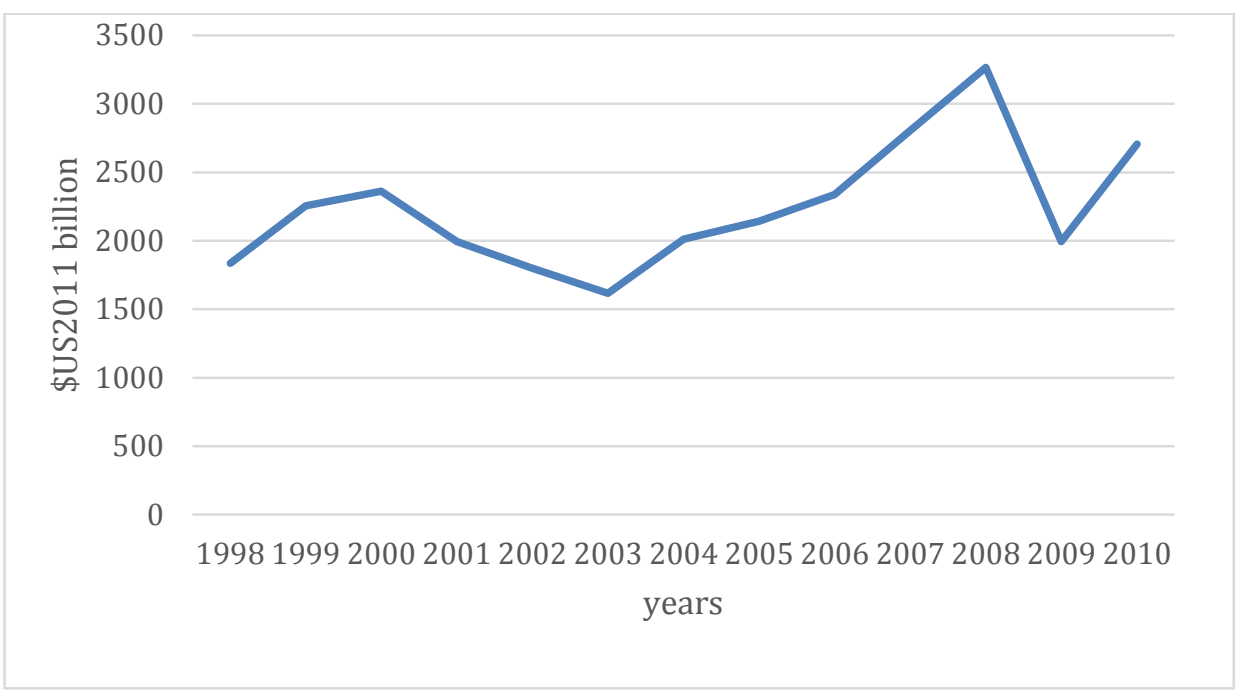

Source: (Chester 2014)

Note: All values converted to 2011 \$US. To convert the 1998 value into 2011 dollars, she has multiplied the 1998 value by 224.4 (the CPI for 2011) and then divided that figure by 163 (the CPI for 1998).

Research by Leigh and Katic (2013) shows that in Australia the share of the top one per cent of wealth holders decreased through most of the twentieth century, from around 35 per cent of all wealth in 1915 to below 10 per cent through the 1970s. It then rose from the late 1970s through to 2010 but most dramatically in the share of the top 0.001 per cent of wealth-holders that trebled between 1984 and 2010. The distribution of wealth has consistently been more concentrated in the UK and USA than in Australia; both of those showed declines in wealth concentration through until the 1980s, and increases afterwards. Chester (2014) 'Ultra high net worth individuals' (those with assets of USD 50m or more) are identifies an overwhelmingly found in the US (where over 35,000 live), then in China (5,000), Germany, Switzerland and Japan, closely followed by the UK and France ((Leigh and Katic 2013:1008)). When we relate the US to other well off countries in 2000 we can see that it comes second in the very high amounts of concentrated wealth held (minus debts and just assets) by their top 10 per cent (See table 2) but still not as high as Switzerland.

Table 2: Percentage of wealth by top $10 \%$ of a selection of adults in various western countries (2000)

\begin{tabular}{|l|c|}
\hline \multicolumn{1}{|c|}{ Country } & $\begin{array}{c}\text { Wealth owned by top 10\% } \\
\text { globally (\%) }\end{array}$ \\
\hline Switzerland & 71.3 \\
\hline
\end{tabular}




\begin{tabular}{|l|c|}
\hline United States & 69.8 \\
\hline Denmark & 65 \\
\hline France & 61 \\
\hline Sweden & 58.6 \\
\hline United Kingdom & 56 \\
\hline Canada & 53 \\
\hline Norway & 50.5 \\
\hline Germany & 44.4 \\
\hline Finland & 42.3 \\
\hline
\end{tabular}

Source: (Domhoff 2014a:9)

Note: Wealth owned by top $10 \%$ globally $(\%)=$ the proportion of wealth in this country held by the top $10 \%$ of wealth holders within that country”.]

Keating et al show that, from 2006 data, from a Report from the World Institute for Development of Economic Research found that 'the top 10\% of the world's adults control about $85 \%$ of global wealth - defined very broadly as all assets (not just financial assets) minus debts” (Keating et al. 2012)

Generally there is a concentration of wealth in stock ownership too. This can translate into crucial control and power over companies exercised by the top one per cent. Table 3 shows that the top 20 per cent of the US stockholders in 2010 held 89.6 per cent of the ownership of stock in the US.

Table 3: Concentration of stock ownership in the US 2001-10

\begin{tabular}{|l|r|r|r|r|}
\hline \multicolumn{3}{|c|}{ Per cent of all stock owned } & & \\
\hline Wealth class & 2001 & 2004 & 2007 & 2010 \\
\hline Top 1\% & 33.5 & 36.7 & 38.3 & 35 \\
\hline Next 19\% & 55.8 & 53.9 & 52.8 & 56.6 \\
\hline Bottom 8\% & 10.7 & 9.4 & 8.9 & 8.4 \\
\hline
\end{tabular}

Source:(From The World Institute for development Economics Research in Domhoff 2014a)

In 2012, four years after a serious global financial crisis, the collective wealth of the top 400 American billionaires was $\$ 2$ trillion or roughly the equivalent of all Russian 2012 GDP.

Next we look at evidence surrounding this top top class fraction and the relations that are affected by financialisation? 


\subsection{Financial Capital}

Finance capital has grown exponentially. Capital exercised through insurance companies, banks and investment brokerages had been considered globally relatively small, compared to retail, manufacture etc. in the 1980s. At that time only 20 per cent of shareholdings in the US were estimated to be hold by finance capital, suggesting finance capital was only a minor part of the sum of the top capital. (Kroll 2013)

After the 1980s finance capital began competing with industry in the late 1980s and 90s to become 'the dominant social formation at the turn of the twentieth century' (Peet 2011). With financial markets, institutions, and elites gaining greater influence over economic policy and economic outcomes system and transforming 'the functioning of economic systems at both the macro and micro levels' in ways that change or elevate 'the significance of the financial sector relative to the real sector [and] transfer income from the real sector to the financial sector' (Herman 1981). In the 2000s banks were able to play with the TBTF fears of government leading to what Mark Carney remarked as 'The expectation that systemically important institutions can privatise gains and socialize losses [which] encourages excessive private sector risk-taking and can be ruinous for public finances.' (Palley 2007:2) The ways that states have been able to help banks through - public transfers used to recapitalize banks, whilst 'asset value guarantees protected balance sheets and supported mergers or takeovers. In some countries, system-wide programs were established for recapitalization, asset purchases, asset guarantees, and debt guarantees.’(IMF 2014)

In our work on global ownership we found an increase in the concentration of ownership and 'if not an increase in bank ownership, then at least an increase in the concentration of ownership in the hands of finance capital' with BlackRock a US founded fund management company in 2009-10, number one shareholder in the USA, Canada and Australia and the number three in Germany (Landier and Ueda 2009) but also in control of 6 per cent of all shares in the world's 300 largest corporations. (Peetz, Murray and Nienhueser 2013) 
When we look at the financialisation of ownership that has occurred, we can see the distribution of the holdings of finance capital in the US, and directly compared them with Herman's (1981) estimate that banks, insurance companies and investment companies controlled a median of 20 per cent of the shares in the 200 largest non-financial US corporations in 1974. Table 4 shows that in 2009-10 the median share ownership in those firms by finance capital had risen to 66 per cent. The median finance share in 2009-10 was 49 per cent, that is, two and a half times the 1974 value. This is strong evidence of the financialisation of ownership since 1974, and a major reversal of Herman's interpretation of the long-term trend through the $20^{\text {th }}$ century, up until the 1970s, of declining finance control.

Table 4: Mean and median shareholdings of fractions of finance capital in top 221 US industrial corporations, 2009-10.

\begin{tabular}{|l|r|r|r|r|}
\hline & Minimum & Maximum & Mean & Median \\
\hline Banks & 0 & 45.9 & 20 & 20 \\
\hline Financial companies & 0 & 40.8 & 16.6 & 15.7 \\
\hline Mutual \& Pension & & & & \\
Fund/Nominee/Trust/Trustee & 0 & 48.8 & 15.4 & 15 \\
\hline Insurance companies & 0 & 21.8 & 7.2 & 6.5 \\
\hline Private Equity firms & 0 & 30.9 & 3.1 & 1.9 \\
\hline Hedge funds & 0 & 1.3 & 0 & 0 \\
\hline Total share of finance capital & 0 & 97.3 & 62.3 & 66.1 \\
\hline $\begin{array}{l}\text { Total finance capital excluding } \\
\text { mutuals/pension funds etc }\end{array}$ & & & & \\
\hline
\end{tabular}

Source: Peetz, D. Target companies database, $\mathrm{N}=221$ US industrial companies. Note figures are minimum estimates as some shareholdings are not recorded,(Peetz and Murray 2013:141)

Investment assets are concentrated tightly in the hands of this top one per cent class, as illustrated here in table 4. In the US, in 2010, the top ten per cent (adding together the top 1\% and next 9\%) of all investors held 91.9 per cent of Business Equity; 81 per cent of Trusts; 93.9 per cent of financial securities and 80.8 per cent of stocks and mutual funds. And so Domhoff said 'since financial wealth is what counts as far as the control of income producing assets, we can say that just $10 \%$ of the people own the United States of America'. (Peetz, Murray and Nienhueser 2013:718) 
Table 5: Wealth Distribution by type of Asset, 2010

\begin{tabular}{|l|l|r|r|r|}
\hline & \multicolumn{2}{|l|}{ Investment assets } & & \\
\hline & \multicolumn{1}{|l|}{ Top 1\% } & Next 9\% & Bottom 90\% \\
\hline Stocks and mutual funds & 35 & 45.8 & 19.2 \\
\hline Financial securities & 64.4 & 29.5 & 6.1 \\
\hline Trusts & 38 & 43 & 19 \\
\hline Business Equity & 61.4 & 30.5 & 8.1 \\
\hline No home real estate & 35.5 & 43.6 & 20.9 \\
\hline total investment assets & 50.4 & 37.5 & 12 \\
\hline
\end{tabular}

Source: In Domhoff 2014, Wolff 2012:Includes direct ownership of stock shares and indirect ownership through mutual funds).

When we look at the wealth distribution of this class fraction we can see the type of concentration described by Marx when he said 'capital [goes] into fewer hands ((Domhoff 2014a:4). This has had severe repercussions for the poor where 'the financial system takes our deposits and lends us money for a home or a small business. It can help determine whether we get wealthier or poorer - and affect whether we can afford to fulfill lifelong dreams of buying property or retiring in comfort’ (Marx 1974:ch. 25, Marx 1978:690-91).

\section{Earned Income}

Income is not as concentrated as wealth. (Bouris 2013) Although this is the case in the US where here is a parallel centralizing of income by the one per cent that has meant that in 2009 held 17 per cent of total income in the US in 2009. Or to put it another way the top one tenth of one per cent 'have more combined pre tax income than the poorest 120 million people' in the US. (Domhoff 2014a:12) ${ }^{\text {i }}$ Most of the increase in the share of the top ten per cent (US) income has been driven by the top one per cent. 
Figure 2: The top one per cent and other high-income groups, 1917-2011 (US)

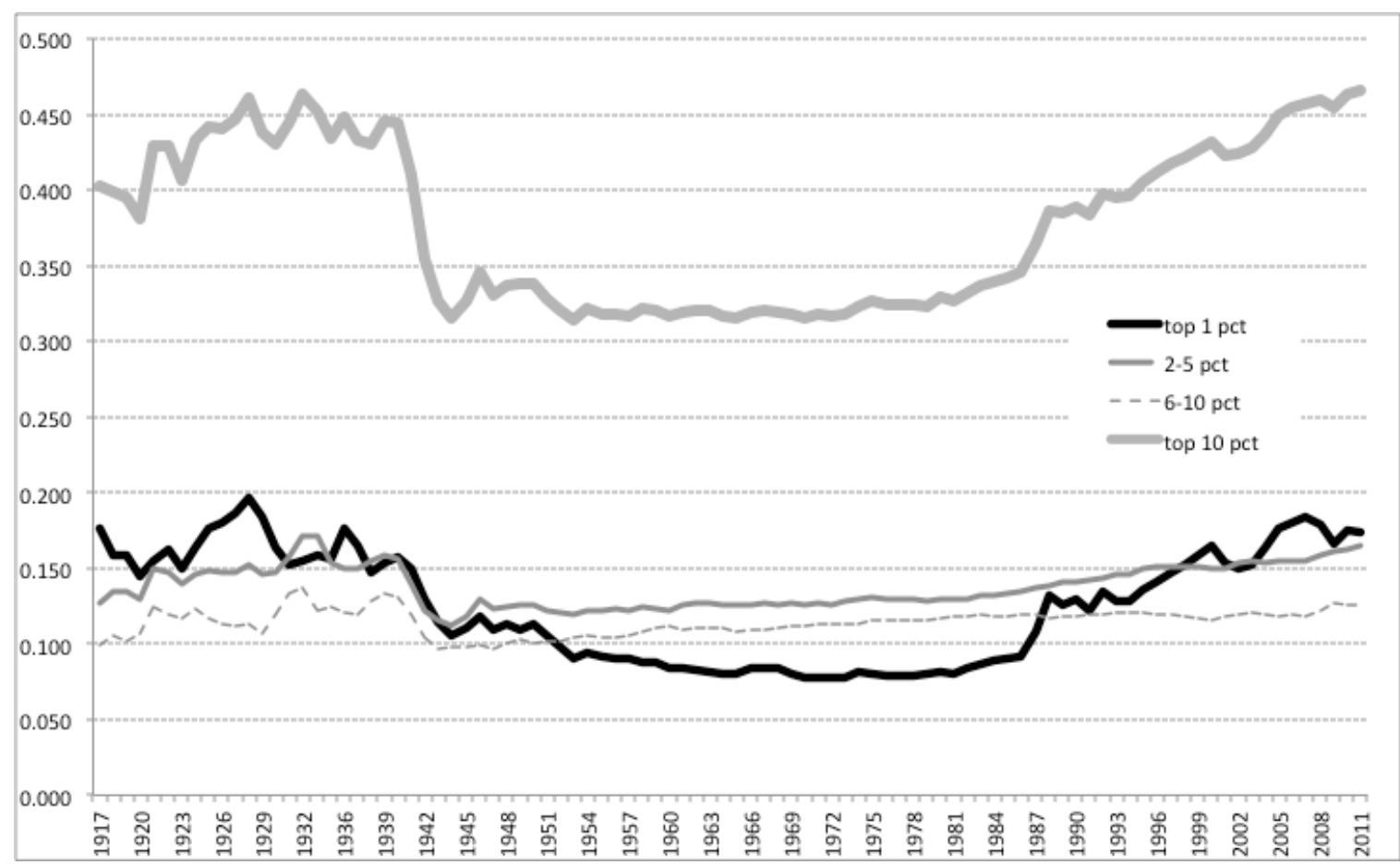

Source: Peetz, D. Derived from income data for top 1,5, and 10 per cent from World Top Incomes Database (http://topincomes.g-mond.parisschoolofeconomics.eu/); reproduced in http://public.tableausoftware.com/shared/MKYGKY76J?:display_count=yes, (Domhoff 2014a:12)

The global flows of capital have reached unprecedented levels that dwarf trade and any other services in the last three decades and this has given those finance capitalists a new edge. (in Peetz, Murray and Nienhueser 2013).

Has this process ever been between countries? No why would it be. There is no logical reasons why capital when it has had to traverse different histories of colonialism, different geographies, different resources and different infra structures.

There have been uneven changes in the distribution of income by geographical blocs. Elsewhere (Dicken 2003:438) have shown that, across the Englishspeaking countries, the share of the top one per cent declined over many decades through the period of the Keynesian compromise and up until and through the 1970s. In each bloc, the share of the top one per cent rose rapidly through the 1980s, 1990s and 2000s - in some cases roughly doubling. In the Northern European countries, which initially had larger top income shares early in the century than the Anglophone countries, there was a steeper decline in inequality 
up to the end of the 1970s. From the 1980s they recorded an increase, but more muted, in the top income share. Other countries (such Southern European and developed Asian countries) generally showed small increases in the top one per cent's share between the 1970s and 2007.

What are the underlying structures of capital?

\section{The Structures and Processes}

The underlying dynamics of capital begin for Karl Marx with profits from workers labour 'What all capitals have in common is their capacity for expanding their value (Verwertungseigenschaft) the fact that they appropriate (directly or indirectly) the surplus-value created in the capitalist production process. The analysis of 'capital in general' must, therefore begin with the production process.' (Marx 1973, Rosdolsky 1977) Workers create surplus value from their labour but for this to expand it has to go into circulation. To explain how Karl Marx’s uses the concepts of abstract capital and the circuit of capital. In the marginal notes of his raft draft of the Grundisse what he says about abstract capital is that it is:

Capital in general, as distinct from particular capitals, does indeed appear 1) only as an abstraction; ... And the distinctions within this abstraction are likewise abstract particularities which characterise every kind of capital, in that it is either their position or negation (e.g. fixed or circulating capital); 2) however, capital in general, as distinct from particular real capitals, is itself a real existence. (Grundrisse 1973: 310)

Rosdolsky remarks that it is evident that Marx speaks about the capital of the entire capitalist class, the 'aggregate social capital' in contrast to particular individual capitals in circulation in the above passage from his rough draft of the Grundrisse. (Rosdolsky 1977)

Movement in the circuit of capital works with surplus value extracted from the work of the worker but it start with the accumulation from past wealth accumulation it starts with M (money): 
..the phase of the production process must be complemented by that of the circulation process. And so the movement of capital becomes a circuit in which forms grow (fixed and circulating) ....In addition these forms are to be understood as distinctions within the abstraction 'capital in general' ... because they 'characterise every kind of capital'. (Marx Grundrisse, 359-60)

The circuit was expressed thus M->C-> (CP+LP)->C’-M'. (Peetz and Murray 2013)

Put simply - Money (M) is used to purchase commodities (C) in the form of raw material and labour and then these inputs are transformed in the process of production (P) (through labour power LP and Commodity production CP) and through this process acquire increased value (C') when sold for increased money (M') this can be put back into production but some money will leave the circuit in private consumption for the capitalist and taxes.

Figure 3: Marx’s Circuit of Capitalist Production

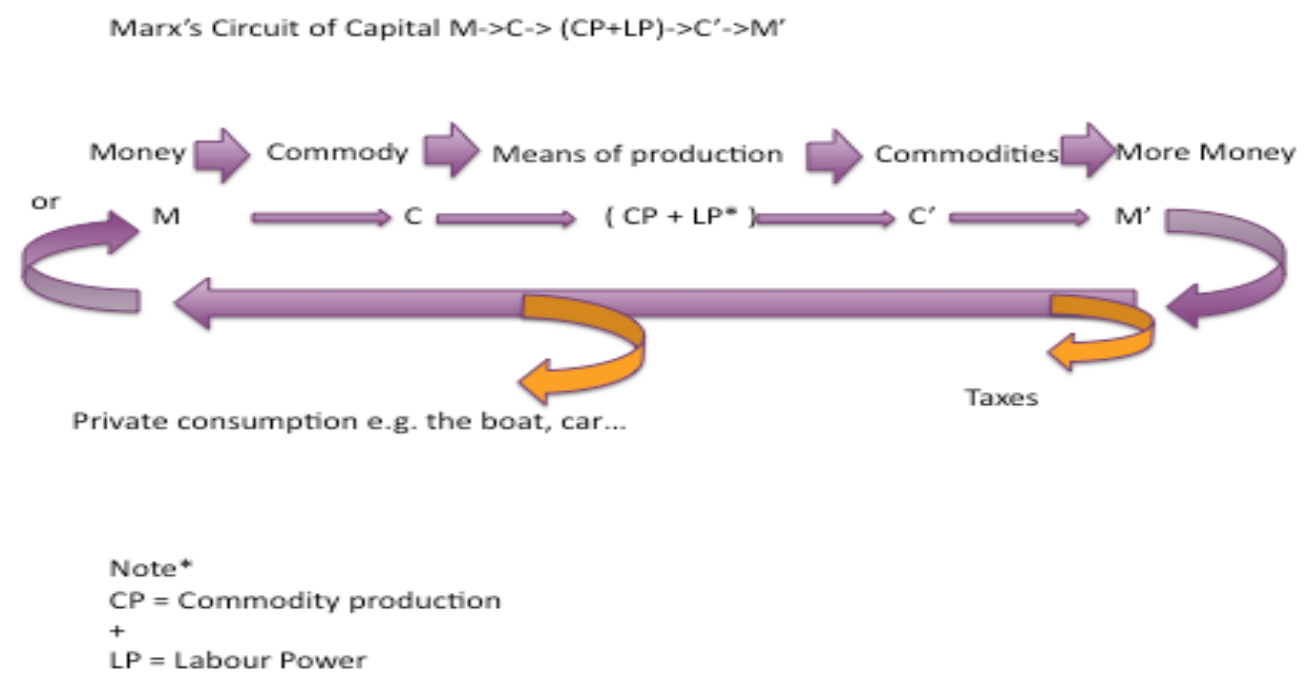

Source: (Marx 1978)

From this single circuit of capital we can extrapolate to look at one capitalist and his or her workers in one factory or at the dynamics underlying capitalist production within a community, town or country and even globally. We can also see that the different parts of capital — industrialists, pastoralists, financiers, 
wholesalers, and retailers — fall into place in the circuit at different stages. Competition between the fractions and within them is the motive dynamic of capitalism for competition is 'none other than the inner nature of capital appearing and realised as the interaction of many capitals', (Marx 1973: 650-651).

Originally describing focusing on industrial production it has been suggested that the original circuit of production identified by Marx has now been transnationalised,(Robinson 2014) whereby P (productive capital) is increasingly decentralizing and where globally produced goods and services are marketed worldwide in increasingly transnational states (TNS) which are "loose network comprised of super-national political and economic institutions with national state apparatus that have been penetrated and transformed by transnational forces" (in Murray, G. 2006: 4 from Marx (1978): 131). This is qualitatively different in form from the transnational financial flows seen earlier.

We have now seen evidence of the scale of wealth and income of this class fraction who are the top one per centers and how their positions overlap between those who hold top wealth, top income and some of their global reach (we have written more extensively on this elsewhere. (Peetz, Murray and Nienhueser 2013) Now we can move from the structural environment to the cases of individual agents of this class fraction and this translates into individuals.

\section{Who are they?}

The one percenters are these people who are the wealthiest by inheritance and or through having top incomes. These men and women are the faces or agents of structural capitalism and we have seen the evidence that shows that this class fraction have power through a disproportionate access to vast amounts of capital (Robinson 2007). These are some examples of the TCC. (See box 1.)

Box 1. The Haniel family have a total turnover in 2011 of $€ 27.4$ billion. The company- Franz Haniel \& Cie, a conglomerate - whose businesses span pharmaceuticals and construction materials, is over 250 years old. The number of their employee's worldwide is approximately 58,141. The family originated in Duisburg in Germany as traders in tobacco, tea, and spices. They were merchant ship owners. In 1805 they diversified by acquiring shares in iron. As one of the first major mine owner in the Ruhr valley, Franz Haniel became by 1834 a major industrialist. The Haniel family has remained with heavy industry and today the 
Haniel Group is in 40 countries with several hundred subsidiaries, 58 billion euro in sales. The head of the family currently is Franz Markus Haniel. There are about 930 family shareholders. Franz Markus Haniel has been Chairman of the Supervisory Board since 2003. Of the 500 members of the clan no one member holds more than 5 percent of the shares in the Group.

Source: (Olsen 2007)

They have been described as a band of hostile brothers Meck (2014) or a 'band of hostile siblings' (Marx 1894a) with conflicting portfolio interests that represent different imperatives over different localities, nations and globally.

An Australian 'miner' who is globally the $5^{\text {th }}$ richest woman on the planet (SMH 2014), BRW: 2014) and $46^{\text {th }}$ on the Forbes list of top wealthiest global billionaires . She is currently in conflict with her children Hope, Bianca and John over their inheritance of a 23.5\% stake in her business (O’Lincoln 1996:15). (See Box2)

Box 2. Australian mining magnate Georgina Reinhart is worth and estimated \$17.7 billion (Forbes: 2014) and \$22billion (BRW: 2014) and she is aged 61. The source of her wealth is mining. Gina Rinehart is still the richest woman in the Asia-Pacific region, even though falling iron ore prices have shaved $\$ 1$ billion off her net worth She is Australian and has been widowed with four children. She is Australia's wealthiest person and expects to a \$7 billion debt package to develop one of the world's largest iron ore mines. She inherited from her father Lang Hancock the family firm, Hancock Prospecting, and is now adding oil and gas to her portfolio.

Source: (Ferguson 2012, SMH 2014)

Ms Reinhart has shown little empathy for those outside her class as evident in this quote "The evidence is inarguable that Australia is becoming too expensive and too uncompetitive to do export-oriented business....African's want to work, and its workers are willing to work for less than \$2 per day. Such statistics make me worry for this country's future."(Forbes 2014c)

Another example of those with a combative right wing approach are the Koch brothers - Charles and David. Their critics (SMH 2012) accuse them of accumulating too much power and using it to promote their economic interests through a network of secretive organizations they call the "Kochtopus." Greenpeace claims that the Charles G. Koch Foundation used a think tank called the State Policy Network to give $\$ 67$ million to climate-denial front groups that 
work to impede policy and regulation designed to stop global warming. (Fisher 2012).

Box 3. David Koch, aged 73 is the $4^{\text {th }}$ wealthiest billionaire with a sum of \$36billion. He is a US citizen. His older brother is Charles Koch who is aged 78 and shares the honour of being the $4^{\text {th }}$ richest billionaire and the CEO of Koch Industries, and US citizen. The world's richest brothers head the nation's second biggest private company with $\$ 115$ billion in sales. Koch Industries owns firms that are involved in refinery, chemicals and financial trading, among many others. They're well known as mega donors for their conservative and libertarian political agenda.

Source: (Forbes 2014a)

Charles Koch had this to say about the introduction of the minimum wage for workers:

What we're saying is, [] these subsidies, this cronyism, this avalanche of regulations, all these things that are creating a culture of dependency. And like permitting, to start a business, in many cities, to drive a taxicab, to become a hairdresser. Anything that people with limited capital can do to raise themselves up, they keep throwing obstacles in their way. And so we've got to clear those out. Forbes (2014a)

Koch has also produced a video ‘Does the Minimum Wage Hurt Workers?'. (Koch 2013)

These top-of-the-top one per centers do not of course have a monopoly on right wing thought as Gregorgy Mankiw points out those on the left include George Soros and Warren Buffett (O'Connor 2013). And it was Buffet who said “There’s class warfare, all right, but it's my class, the rich class, that's making war, and we're winning.” (Mankiw 2014)

Cultural imperialism, employed by this class it is claimed acts as a mechanism to produce consent to the inequities wealth just described (Buffett 2014). Through popular music, jazz, TV, cinema, fashion, literature, architecture, fastfood, or language, our politics, our moral beliefs and our ideologies are all, it is suggested, used to dull resistance and help legitimate the status quo. One of the most enthusiastic transmitters of culture imperialism is Keith Rupert Murdoch.

Box 4: Rupert Murdoch is 82, US Citizen with a total wealth of $\$ 13.4$ billion. He 
is ranked as the $30^{\text {th }}$ top billionaire (September 2013). Murdoch in 2013 divide his News Corp. media and entertainment empire into two unequal parts: the big one consisting mainly of TV and film properties (21st Century Fox) and a smaller one for newspaper and book publishing (News Corp.) His net worth has climbed \$4 billion over the past year because of his large stock ownership of rising sharply in value.

Source: (Forbes 2014b)

Recent scandals that involved Murdoch's newspaper staff allegedly using phone tapping techniques revealing disturbingly close links between the magnate, the state and the police (Durgy 2013). The role of the nation state arbitrating as it does over property and property rights through the law courts, the organization and disciple of workers; the passing on of cultures of work through education system, and its acts as the 'independent' regulator of issues of trade, foreign investment and industry; means that maintaining this relationship with state 'footmen' (Hamm 2010a) and women will always be a significant priority for top business.

Someone who allegedly maintains strong ties to the state is Larry Fink, the CEO of BlackRock which controls over 6 per cent of all shares in the world's 300 largest listed corporations (Murray and Peetz 2012) His global fund management company holds an estimated \$3.8 trillion in assets under management worldwide. And it is held that he is often the first phone call for governments and businesses with questions, with clients including the U.S., Sweden, Germany, General Electric and JP Morgan Chase and the treasury secretary - Tim Geithner (Peetz and Murray 2012:141). Fink as CEO earns only a modest \$500,000 p.a (Lenzner 2014). However, this is supplemented with a bonus of $\$ 8,125,000$ p.a, plus restricted stock awards $\$ 13,060,606$ p.a. plus another compensation of $\$ 192,250$ p.a. giving him a total income of $\$ 21,877,856$ pa.

Box 5. Larry Fink is an original founder and current CEO of BlackRock. He is 61 years old and a US citizen resident living in N. Y. BlackRock has an estimated \$3.8 trillion in assets under management though this may understate the stretch of thisthe world's largest money manager. Fink wields considerable political power his decisions impact on the retirement savings of millions of workers. There are $62 \%$ (\$2.1 trillion) of BlackRock's total long-term-assets under management are for institutional investors, including pensions.

Source: (Forbes 2014e) 
Influence is embedded into the networks that the top-of-the-top one per cent are free to create and maintain. This TCC are active in global civil society attending policy group-clubs - such as the Mont Pelerin Society (first convened in 1947), the Bilderberg (1952), the World Economic Forum, (1971), The Trilateral Commission (1973) and the World Council for Sustainable Development (1995) Forbes (2014d) (Harris 2012). Apart from being able to share exclusive political clubs ruling class members join the same sporting clubs (for more read Carroll and Fennema 2002:39). This class fraction are also likely to share expensive and extensive consumer patterns, to go to similar elite schools and universities and to live in segregated gated communities (Carroll 2010, Murray 2006). The other important aspect of their power, that is not explored here is their part played in the military, security services and the structures of ongoing wars. This has been discussed elsewhere. (Hamm 2010a)

We have seen that most TCC are men and white (see Dicken 2007, Robinson 2012b). Although more women are amongst the ranks of the world's wealthiest they are still a small minority of 138 from a total of 1,426 on the new 2013 Forbes list that is women are only 9 per cent of the billionaires (Patterson 2013). Another female exception is Susan Klatten, Germany’s richest woman. She inherited a 12.6 per cent stake in automaker BMW from her late father Herbert Quandt. (See Box 6)

Box 6. Susanne Klatten Germany's richest woman started with a $12.6 \%$ stake in automaker BMW inherited from her father Herbert Quandt. Susanne, her brother Stefan Quandt and her mother Johanna Quandt together own nearly 50\% of BMW, which has continued to grow despite weakness in Europe. Instead sales in the U.S. and China have become more important. A trained economist, Klatten also controls chemical manufacturer Altana and holds stakes in a wind power company Nordex AG, carbon and graphite producer SGL and Geohumus, which focuses on developing a water storing granulate to be used in agriculture. In 2012 Klatten bought stakes in early stage Dutch biotech company Paques and used oil-recycling company Avista Oil of Germany.

Source: (Dolan 2013)

Can these very wealthy individual's success be explained through their exceptional skill? Is there a high correlation between earnings and skill, which in turn would require a high degree of correlation between skill demonstrated in one 
year and skill demonstrated in the following year. (If the correlation is low, and good results cannot be reproduced from one year to the next, then we can conclude that what is proclaimed to be 'skill' is in all likelihood 'luck'.)

Karl Hans Albrecht, the reclusive 94-year-old billionaire who inherited his mother's business and turned it into - the Aldi group - would be a good example of this demonstrated high competence and skill in CEOs (see Box 7).

Box 7: Karl Hans Albrecht was born on the 20 February 1920, and is now at 94 the richest German alive. He is worth $€ 26$ billion from the Aldi Group. With his brother Theo he founded the discount no frills supermarket chain Aldi splitting ownership into two parts in 1961 (North-Theo and Sud-Karl). The origin of the business was their mother's pre ww2 grocery store that they turned into a transnational discount supermarket chain. As of October 2012, Albrecht is listed as one of the richest people in the world with an estimated net worth of US\$22.6 billion. Karl's giant German discount supermarket chain, with its 4,600 stores in 9 countries, including 1,200 locations is found in 32 U.S. states. Monies from the private company grew at an estimated 9\% in 2012 to $\$ 46.5$ billion. Growth was strongest in Europe particularly UK and Ireland. Theo died in 2010. Karl Albrecht resigned from operational business in 1994 by stepping down from the Aldi board in 2002 his daughter, Beate Heiser, and one of her sons, Peter Max, represent the family on the board of trustees.

Source: (Forbes 2014f)

However despite this example research shows that the pay of CEOs and directors does not consistently correlate positively with performance, and can sometimes correlate negatively with it (Peetz 2010, Shields, O’Donnell and O’Brien 2003).

In sum these TCC may be extremely clever exceptionally generous, beautiful and caring individuals or the reverse - it is irrelevant - because they are what they are because of their chance relationship to capital. It is this happenstance that has landed them into a fluid capital accumulating process that is uneven and geographically diverse but advantageous to them (Ferri 2010, Peetz 2010, Philips 2010, Shields, O’Donnell and O’Brien 2003, Yernack 2005).

\section{Conclusion}

Theorists of the global school of capitalism (GSC) argue that there has been a qualitatively new twenty-first century transnational capitalism in the process of emerging (Carroll 2010, Dicken 2007, Harris 2012, Murray and Peetz 2012:46, Robinson 2014:4, Sklair 2005, Sprague 2009, Strauna 2012). From this process 
has come the top-of-the-top one per cent either through their wealth or income or both. (Robinson 2012a) The qualitatively new environment that nurtures them and which they inhabit is characterized by transnational capital that now penetrates all global regions and all nation states, Nation states now operate with and through transnational state apparatus usually in the form of large networks organized to facilitate capital and control labour (e.g. WTO, WB, IMF). (Domhoff 2014a) The emerging transnational capitalist class are richly embedded in global circuits of accumulation. These circuits are currently experienced in a period of financialisation that is unique to this period of post -Keynesian compromise.

The flip side of this is that there is evidence to show that financialisation has brought new lows to the polarization of class, exploitation and domination which have intensified with an accentuated north south dimension (Carroll 2010:10, 37, Robinson 2014). Downward trends in the real productive capital have shrunk the size of the blue-collar job market. Non-financial firms are dependent on the financial sector more than previously. The results of the dominant source of profit now being held from the financial sector has weakened labour friendly policies and institutions added to which are the tax-supportive policy of the states to business- no matter what (Kus 2012). These factors all contribute to the growth of inequality.

The one per centers, the wealthy, those on the top incomes and TCC are all distinct but overlapping categories to describes the (white) men and (few) women who hold power through their ownership and/or control of capital and who are, thereby directly or indirectly, able to act hegemonically toward us based on their ownership and control of capital.

\section{Bibliograpy}

Alvaredo, F., A. Atkinson, T. Piketty and E. Saez. 2013. "The Top 1 Percent in International and Historical Perspective." NBER Working Paper No. 19075. NBER Program(s): )

Alveredo, F, A. Atkinson, T Piketty and E. Saez. 2013. "The Top 1 Percent in International and Historical Perspective, ." Journal of Economic Perspectives 27(3):3-20.

Beder, S. 2006. Suiting Themselves: How Corporations Drive the Global Agenda. London: Earthscan. 
Bouris, M. . 2013. "Five Steps to a Fairer Financial World." in Sydney Morning Herald. Sydney: Fairfax.

Buffett, W. 2014. "Quotes."

Carroll, W. 2010. The Making of Transational Capitalist Class: Corporate Power in Th 21st Century. London: Zed Books.

Carroll, W.K and M. Fennema. 2002. "Is There a Transnational Business Community?". International Sociology 17(3):393-420.

Chester, J. 2014. "Global Billionaires and Their Distribution."

Cockett, R. . 1995. Thinking the Unthinkable: Thnink Tanks and the Econommic Counter Revolution 1931-1983. London: Harper Collins.

Connell, R. and N. Dados. 2014. "Where in the World Does Neoliberalism Come From?". Theory and Society.

Dicken, P. 2007. Global Shift Mapping the Changing Contours of the World Economy. London: Sage.

Dicken, P. . 2003. Global Shift: Reshaping the Global Economic Map in the 21st Centuary. New York: Sage.

Dolan, K. . 2013. "The World's Richest Women in 2013."

Domhoff, W. G., ed. 2014a. Who Rules America.Net: Power, Politics, and Social Change. (http://www2.ucsc.edu/whorulesamerica/).

Domhoff, W. G. 2014b. "Power in America Wealth, Income, and Power." Retrieved.

(http://www2.ucsc.edu/whorulesamerica/power/wealth.html).

Durgy, E. 2013. "The Worlds Richest Billionaires: Full List of the Top 500." Forbes.

Ferguson, A. 2012. "Rinehart World's Richest Woman." BRW May

Ferri, Richard E. 2010. The Power of Passive Investing. Hoboken, NJ: Wiley.

Fisher, D. 2012. "Inside the Koch Empire: How the Brothers Plan to Reshape America." in Forbes.

Forbes. 2014a. "David and Charles Koch."

Forbes. 2014b. "Murdoch."

Forbes. 2014c. "Australia's 50 Richest."

Forbes. 2014d. "The World's Most Powerful People." Forbes.

Forbes. 2014e. "Powerful People."

Forbes. 2014f. "Karl Hans Albrecht " Forbes.

Friedman, M and R. Freidman. 1980. Free to Choose: A Personal Statement. New York: Harcourt Brace Jovanovich.

Grossman, E. and C. Woll. 2013. "Saving the Banks: He Political Economy of Bailouts." Comparative Political Studies.

Hamm, B. 2010a. "The Study of Futures and the Analysis of Power." Futures:1007-18.

Hamm, B. 2010b. "The Studies of the Future and the Analysis of Power." Futures (42):1007-18.

Harris, J. 2012. Outward Bound, Transnational Capitalism in China, Edited by G. Murray and J. Scott. Cheltenham: Edward Elgar.

Henwood, D. 2005. "Wall Street." Retrieved. (http://www.wallstreetthebook.com/WallStreet.pdf).

Herman, E. S. . 1981. Corporate Control, Corporate Power. Cambridge: Cambridge University Press. 
Holden, M. . 2014. "Tony Blair Offered to Help Rupert Murdoch over Phone Hacking." in The Sydney Morning Herald.

IMF. 2014. "Global Financial Stability Report: Moving from Liquidity-toGrowth Driven Markets." Edited by IMF. Retrieved. (http://www.imf.org/External/Pubs/FT/GFSR/2014/01/pdf/text.pdf l.

Keating, Giles, MIchael O'Sullivan, Anthiny Shorrocks, James B Davies, Rodrigo Lluberas and Antonios Koutsoukis. 2012. "Global Wealth Report 2011." Vol. Zurich: Credit Suisse, Research Institute.

Koch, C. 2013. "As Obama Pushes for Minimum Wage Increase, Billionaire Charles Koch Rails against It with Media Campaign." Forbes.

Krippner, N. . 2005. "The Financialisation of the American Economy." Socio Economic Review 3(2):173-208.

Kroll, L. . 2013. "Inside the 2013 Forbes 400: Facts and Figures on Americas Richest." Forbes.

Krugman, P. 2011. "We Are the 99.9\%." in New York Times. New York.

Kus, B. 2012. "Financialisation and Income Inequality in Oecd Nations: 19952007." The Economic and Social Review 43(4).

Landier, A. and K. Ueda. 2009. "The Economics of Bank Restructuring: Understanding the Options," Imf, (" Vol. International Monetary Fund. Washington: .

Leigh, A. and P. Katic. 2013. "Top Wealth Shares in Australia 1915-2012."

Lenzner, Robert 2014. "Billionaire Ceo Larry Fink Sees a Manufacturing Renaissance in the Us." Forbes.

Leopold, L. . 2009a. "What Recession? As the Economy Crashed around Them 400 Richest Americans Lined Their Pockets with \$30billion." Alternet.

Leopold, L. . 2009b. "What Recession? As the Economy Crashed around Them, 400 Richest Americans Lined Their Pockets with \$30 Billion.". Alternet.

Letts, S. 2014. "Billions Hidden in to Too-Big-to-Fail Banks." ABC Online. (http://www.abc.net.au/news/2014-04-02/billions-in-hiddensubsidies-going-to-too-big-to-fail-banks/5361150).

Lopez, Ricardo 2013. "The Rich Have Now Regained All Their Lost Riches." Forbes

Madoff, R. 2010. Immotality and the Law: The Rising Power of the American Dead. Cambridge: Yale University Press.

Mankiw, N. Gregory. 2014. "Response from N. Gregory Mankiw." Journal of Economic Perspectives-Volume 28, Number 1-Winter 2014-Pages 243-248 28(1):243-48.

Marx, K 1974. Capital, Vol. 2. London: Lawrence and Wishart.

Marx, K. 1894a. "Theories of Surplus Value." Vol. 3. Retrieved. (http://www.marxists.org/archive/marx/works/1894-c3/ch15.htm).

Marx, K. 1978. Capital, Vol. 2. Moscow: Progress Publishers.

Marx, K. . 1894b. Capital, the Process of Capitalist Production as a Whole, Vol. 3. New York: International publishers.

Marx, K. . 1973. Grundrisse, Foundations of the Critique of Political Economy (Rough Draft). Harmondsworth: Penguin Books.

Marx, K. . 1981. Capital. New York: Vintage.

McMichael, P. 1996. Development and Social Change: A Global Perspective. CA: Pine Forg.: Thousand Oaks, . 
Meck, G. 2014. "The Haniel Family." Forbes.

Mills, C. W. . 1958. "Structure of Power in American Society." British Journal of Socoiolog 9(1).

Murray, G. and D Pacheco. 2000. "The Ideas Industry: Australasian Think Tanks in the 1990s', ." Marxist Interventions (http://www.anu.edu.au/polsci/marx/interventions, ).

Murray, G. and D. Peetz. 2012. "The Financialisation of Global Corporate Ownership." in Financial Elites and Transnational Business: Who Rules the World?, edited by G. Murray and J. Scott. Cheltenham: Edward Elegar.

Murray, G. . 2004. "Think Tanks, Economic Liberalism and Industrial Relations." in New Economies: New Industrial Relations,, Vol. Proceedings of the 18th AIRAANZ conference, edited by M. Barry, Brosnan, P. . Noosa, Queensland, Australia: Association of Industrial Relations Academics of Australia and New Zealand,.

Murray, G. . 2006. Capitalist Networks and Social Power in Australia and New Zealand. Aldershot: Ashgate.

Norris, F. 2010. "Off the Charts: In '08 Downturn Some Managed to Eke out Millions;." in New York Times.

O'Connor, C. 2013. "As Obama Pushes for Minimum Wage Increase, Billionaire Charles Koch Rails against It with Media Campaign."

Forbeshttp://www.forbes.com/sites/clareoconnor/2013/08/08/asobama-pushes-for-minimum-wage-increase-billionaire-charles-kochrails-against-it-with-media-campaign/.

O'Lincoln, T. , ed. 1996. Wealth, Ownership and Power, the Ruling Class Edited by R. Kuhn and T. O'Lincoln. Melbourne: Longmans. .

Olsen, P. 2007. "Metro Drops on Lost Bid Hopes." Forbes.

Palley, T. . 2007. "Financialization: What It Is and Why It Matters." Vol. Working Papers No. 525, . Washington, D.C: The Levy Economics Institute and Economics for Democratic and Open Societies

Palloix, C. . 1977. "The Self-Expansion of Capital on a World Scale,." Review of Radical Political Economics 9(2):3-17.

Patterson, R. . 2013. "Transnational Capitalist Class: What's Race Got to Do with It? Everything!". Globalizations 10(5):673-90.

Peetz, D. 2010. "Asymmetric Reference Points and the Growth of Executive Remuneration." Paper presented at the Work in Progress: Crises, Choices and Continuity, AIRRANZ, February 2010., Sydney.

Peetz, D. and G. Murray, eds. 2012. The Financialisationof Global Ccorporate Ownership, , Edited by G. Murray and J. Scott. Cheltenham: Edward Elgar.

Peetz, D. and G. Murray. 2013. " Plutonomy and the One Percent." in Challenging the Orthodoxy: Reflections on Frank Stilwell's Contribution to Political Economy., edited by S. Schroeder and L. Chester. Heidleberg: Springer.

Peetz, D., G. Murray and W. Nienhueser. 2013. "The New Structuring of Corporate Ownership ". Globalisations 10(5):711-30.

Philips, Christopher B. 2010. "The Case for Indexing." Valley Forge, Pa: The Vanguard Group. 
Robinson, W. I. 2007. Theory and the Rise of Globalization Studies, Edited by G. Ritzer. Oxford: Blackwell.

Robinson, W. I and J. Harris. 2000. "Toward a Global Ruling Class? Globalization and the Transnational Capitalist Class." Science and Society 64(1):11-54.

Robinson, W. I. 2014. “Global Capitalism, Global Crisis.” Routledge.

Robinson, W. I. . 2012a. "Global Capitalism and Its 'Anti-Human' Face: Organis Intellectuals and Interpretations of the Crisis." Globalisations $10(5): 659-71$.

Robinson, W. I. . 2012b. "Global Capitalism Theory and the Emergence of Transnational Elites." Critical Sociology 38(3):349-63.

Rosdolsky, R. . 1977. The Making of Marx's Capital. London Pluto Press.

Shields, J., M. O’Donnell and J. O’Brien. 2003. "The Bucks Stop Here: Private Sector Executive Remuneration in Australia." Vol. Report prepared for the Labor Council of New South Wales University of NSW.

Sklair, L. 2005. "The Transnational Capitalist Class and Contemporary Architecture in Globalizing Cities." International Journal of Urban and Regional Research 29 (3):485-500.

Sklair, L. 2002. "Democracy and the Transnational Capitalist Class." Paper presented at the AAPSS, May ( http://www.unimuenster.de/PeaCon/global-texte/r-m/144sklair.pdf).

SMH. 2012. "World's Media Pan Rinehart's \$2 a Day African Miner Comments."

SMH. 2014. "Gina Rinehart Tumbles Down Forbes Rich List March 4th, Sydney Morning Herald." in Sydney Morning Herald.

Sprague, J. 2009. "Transnational Capital Class in the Global Financial Crisis." Globalisations 6(4).

Strange, S. 1996. Mad Money. Manchester: Manchester University Press.

Strange, S. . 1986. Casino Capiatlism. Oxford: Blackwell.

Strauna, J. 2012. "The Icon Project: The Transnational Capitalist Class in Action." Globalisations 10(5):747-63.

Strauna, J. . 2009. "Toward a Theory of Global Proletairian Fractions." Perspectives on Global Devlopment and Technology 8(2):230-60.

Van Fossen, A. 2012. The Transnational Class and Tax Havens, Edited by G. Murray and J. Scott. Cheltenham: Edward Elgar.

Von Hayek, F. 1944. The Road to Serfdom. Chicago, USA: The University of Chicago Press.

Watts, N. 2012. "David Cameron Acknowledges There May Be More Rebekah Brooks Texts." in The Guardian.

Wolff, E. . 2012. The Asset Price Meltdown and the Wealth of the Middle Classes. New York: New York University.

Yernack, David. . 2005. "Flights of Fancy: Corporate Jets, Ceo Perquisites and Inferior Shareholder Returns." Journal of Financial Economics 80:21142. 
1. This section is based on a paper Murray, G. \& Peetz, D. 'Plutonomy of the One Per Cent' Invited Conference dedicated to Professor Frank Stilwell, University of Sydney, May, 2013 